\title{
Site fidelity of Sotalia guianensis (Cetacea: Delphinidae) in Sepetiba Bay, Rio de Janeiro, Brazil
}

\author{
Mariana F. Nery ${ }^{1,2}$; Mariana de A. Espécie ${ }^{2} \&$ Sheila M. Simão ${ }^{2}$ \\ 1 Instituto de Ecología y Evolución, Universidad Austral de Chile. Casilla 567, Valdivia, Chile. E-mail: maribioufscar@yahoo.com.br \\ 2 Departamento de Ciências Ambientais, Instituto de Florestas, Universidade Federal Rural do Rio de Janeiro. Rodovia BR 465, \\ km 7, 23890-000 Seropédica, Rio de Janeiro, Brasil.E-mail: mariana_especie@hotmail.com, smsimao@ufrri.br
}

\begin{abstract}
Estuarine dolphins, Sotalia guianensis (Van Bénéden, 1864), were identified in Sepetiba Bay $\left(22^{\circ} 35^{\prime}\right.$, $44^{\circ} \mathrm{O} 3^{\prime} \mathrm{W}$ ), state of Rio de Janeiro, Brazil, between February 1994 and July 2006 using the photo-identification method. A total of 72 surveys resulted in the identification and cataloguing of 217 individual dolphins. Seventynine $(36 \%)$ were resighted at least once during the study period. The average interval between resightings was $40,6 \pm 31,1$ months. Large numbers of mother-and-calf pairs were recorded during the 12 years and new individuals were frequently encountered in the photographic records. These results suggest that part of the dolphin population is more consistently found in Sepetiba Bay, probably for feeding and reproduction, while other individuals use the Bay only sporadically.
\end{abstract}

KEY WORDS. Estuarine dolphin; habitat use; photo-identification.

RESUMO. Fidelidade de área de Sotalia guianensis (Cetacea: Delphinidae) na Baía de Sepetiba, Rio de Janeiro, Brasil. Indivíduos da população dos golfinhos estuarinos, Sotalia guianensis (Van Bénéden, 1864), da Baía de Sepetiba $\left(22^{\circ} 35^{\prime} \mathrm{S}, 44^{\circ} \mathrm{O} 3^{\prime} \mathrm{W}\right)$ Estado do Rio de Janeiro, sudeste do Brasil, foram catalogados pelo método de foto-identificação durante o período de fevereiro de 1994 a julho de 2006 . Foram conduzidas 72 expedições de barco, resultando na identificação e catalogação de 217 botos. Destes 79 (36,4\%) foram recapturados pelo menos uma vez durante o período de estudo; o intervalo médio entre as recapturas foi de 40,6 $\pm 31,1$ meses. A presença de pares de mães-filhotes foi numerosa ao longo dos 12 anos de estudo e novos indivíduos foram constantemente identificados na área. Os resultados sugerem que parte desta população depende substancialmente do habitat fornecido pela Baía de Sepetiba, tanto para alimentação quanto para fins de reprodução, apesar de haver indivíduos que pouco se utilizam desta área.

PALAVRAS-CHAVE. Golfinho estuarino; fidelidade de habitat; foto-identificação.

The small estuarine dolphin, Sotalia guianensis (Van Bénéden, 1864) of coastal and estuarines waters of Central and South America is common from southern Brazil $\left(27^{\circ} 35^{\prime} \mathrm{S}\right.$, $48^{\circ} 35^{\prime} \mathrm{W}$ - SimõEs-Lopes 1988$)$ to Nicaragua $\left(14^{\circ} 35^{\prime} \mathrm{N}, 83^{\circ} 14^{\prime} \mathrm{W}\right)$ and may be found as far north as Honduras $\left(15^{\circ} 58^{\prime} \mathrm{N}, 79^{\circ} 54^{\prime} \mathrm{W}\right.$ - CARr \& Bonde 2000). This species has been found at a total of 49 published locations in Brazil (Borobia et al. 1991, Azevedo \& van Sluys 2005, Rossi-SANTOS \& Podos 2006). While abundant along the South American coast, information about this dolphin is considered insufficient by the International Union for Conservation of Nature and Natural Resources (IUCN 2006) for conservation purposes, particularly with respect to population dynamics, ecology, residence patterns, habitat and social interactions.

This species is difficult to study in nature due to its small size, its tendency to avoid approaching humans, its preference for dark estuarine waters and lack of sexual dimorphism. To overcome such problems, photo-identification methods are of- ten used to identify individual animals in mark-recapture studies. With a library of photographs and sighting information, individuals can be recognized by natural and unique skin patterns and scars (Würsig \& JefFerson 1990). Population size (HAMmOND et al. 1990), residence and movement patterns within an area (Würsig \& Würsig 1977, ScotT et al. 1990, Weigle 1990), and group structure (BIGG et al. 1990, Wells 1991) have all been studied with this method. In Brazil, photo-identification as a tool to study site fidelity in $S$. guianensis is relatively recent (Flores 1999, Santos et al. 2001, Azevedo et al. 2004, Rossi-Santos et al. 2007).

Since 1994, our group has studied this dolphin in Sepetiba Bay (state of Rio de Janeiro, Brazil; $22^{\circ} 35^{\prime}$ S, $44^{\circ} 03^{\prime}$ W, Fig. 1), in part to create a visual database for the study of the ecology and the behaviour of estuarine dolphins. Sepetiba Bay is a semiclosed coastal lagoon complex with an area of $519 \mathrm{~km}^{2}$ with diverse environments including beaches, peninsulas, islands, 


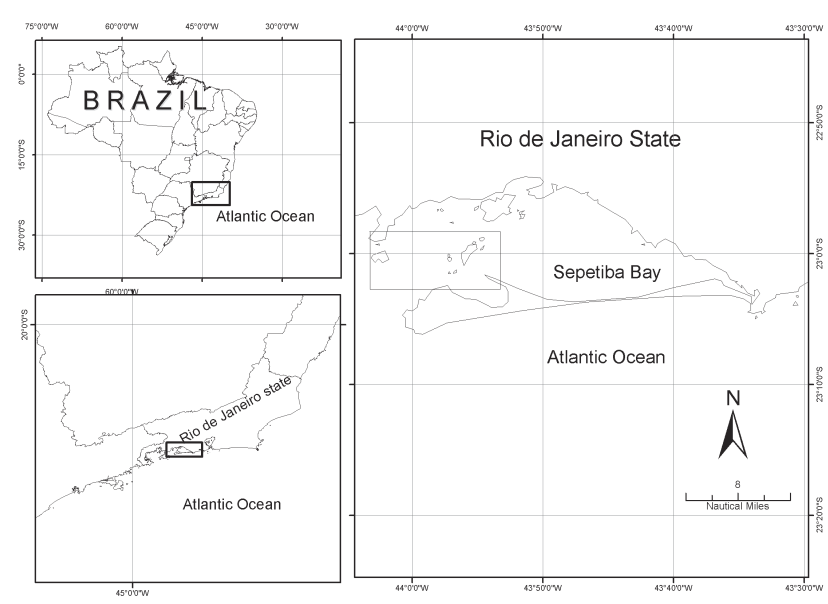

Figure 1. A map of Sepetiba Bay (Southeastern Brazil) showing the area most used by the estuarine dolphins.

rocky cliffs, and mangrove and inter-tidal swamps. Much of the inlet complex is shallow ( $6 \mathrm{~m}$ in depth), but in some areas, for example, between islands, may reach $47 \mathrm{~m}$ (Muene \& VALENTINI 1998).

The bay suffers from extensive anthropic activities. More than 400 factories (chemical, metal, rubber and printing) surround this ecologically important area (MueHE \& VALENTINI 1998). Industrial and agricultural wastes, together with pollution from a nearby and expanding port, are constant inputs into the bay and constitute a grave threat to the local wildlife (MARQues et al. 2002).

In this paper, we present information gathered over a 12-year period of observation of $S$. guianensis population (sensu MaYr 1977) inhabiting Sepetiba Bay. The results presented herein provide an insight into site fidelity and population dynamics of the estuarine dolphin that should be important in the design of future conservation projects.

\section{MATERIAL AND METHODS}

Site fidelity is defined as the tendency of an animal to occupy an area or to return to a previously occupied area over some period of time (White \& Garrot 1990). To examine fidelity, boat surveys were conducted in the Sepetiba Bay from February 1994 to August 2006. Photographs of the dorsal region, including the dorsal fin, of estuarine dolphins were taken to allow individual identification. The sampling effort was not equally distributed throughout the study period. Field work was carried out from a seven meters boat that cruised at four knots during favourable conditions. Favorable conditions were at the state of the sea $<3$ on the Beaufort scale, and no surveys ocurred when the state of the sea was $\geqslant 3$, when photography is difficult or impossible (Simão et al. 2000). Survey teams comprised a vessel operator, a data recorder and one or two experienced photographers. The boat moved randomly until one or more groups of dolphins were sighted.. The geographical position of the dolphins was marked and subsequently plotted on a nautical chart. Pictures were taken using $35 \mathrm{~mm}$ cameras (Nikon N80 with a Nikon AF 70-300 mm zoom lens, or Canon EOS with a Canon EF 75-300 mm zoom lens). Color and black/ white films of speed 100 or 400 ASA were used depending on the light. Only photos that allowed clear identification of individual animals were used (in focus, un-obscured, with the dorsal fin relatively perpendicular to the plane of the photograph, with the dorsal fin large enough to identify small notches). Selected photographs were compared visually by at least two experienced researchers in matching dorsal fins photographs, following Defran et al. (1990).

Two error types are most common with photoidentification. First, false negatives, when two sightings of different individuals are classified as one. Second, false positives, when two images of the same individual are classified as two different animals; both resulting in population estimations biased (Gunnlaugsson \& Sigurjónsson 1990, Stevick et al. 2001). We believe that we minimized or eliminated those potential errors by the use of high quality photographs and two researchers examing those photographs.

\section{RESULTS}

A total of 72 surveys during the 12 years (excluding 1996) found that estuarine dolphins inhabit Sepetiba Bay area throughout the year (Tab. I, Fig. 2). Dolphins were found within only $28 \%$ of the bay, an area of roughly $145 \mathrm{~km}^{2}$ area (Fig. 1). Dolphins were seen during every expedition and were found in groups ranging from 2 to $200(80.5 \pm 51.1)$ individuals. Individuals were observed performing aerial, hunting, social behaviour, or travelling (SIMÃo et al. 2000). Groups with mother-

Table I. Number of surveys, and catalogued and resighted Sotalia guianensis dolphins in Sepetiba Bay between February 1994 and August 2006.

\begin{tabular}{lccc}
\hline Years & Number of surveys & New identifications & Resightings \\
\hline 1994 & 4 & 7 & 0 \\
1995 & 1 & 16 & 1 \\
1997 & 2 & 17 & 3 \\
1998 & 18 & 65 & 50 \\
1999 & 4 & 11 & 10 \\
2000 & 8 & 17 & 16 \\
2001 & 10 & 26 & 40 \\
2002 & 5 & 3 & 6 \\
2003 & 5 & 35 & 33 \\
2004 & 8 & 14 & 19 \\
2005 & 5 & 4 & 6 \\
2006 & 2 & 2 & 2 \\
\hline Total & 72 & 217 & 186 \\
\hline
\end{tabular}




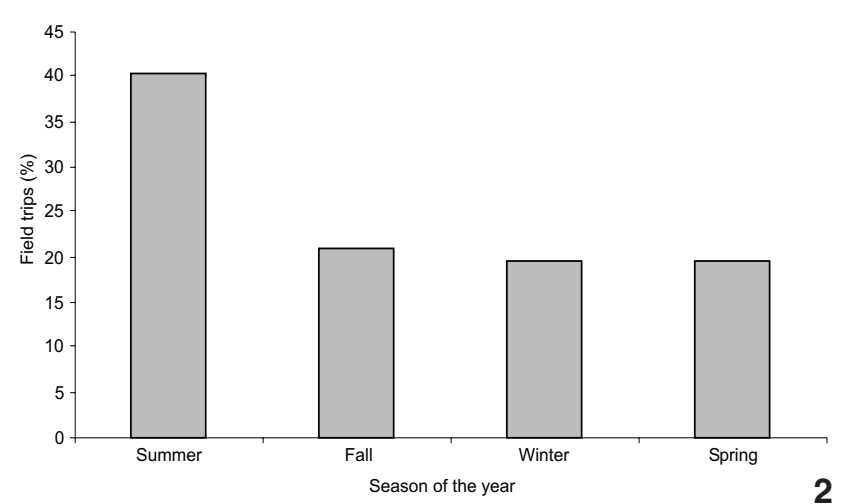

Figures 2-3. (2) Distribution of census periods by season for the 12 years of study; (3) distribution of the photo-identified dolphins and the number of sightings for each animal.

calf pairs were frequent (80\%) while those comprising only adults were much less common (20\%).

A total of 217 animals were identified and catalogued, with 186 resightings. Each of these was clearly recognized from the silhouette of the dorsal fin and/or from scars of other visibile features near the dorsal fin. Annual resighting was correlated with the number of surveys carried out each year (Spearman $\left.r_{s}=0.755, \mathrm{n}=12, \mathrm{p}=0.011\right)$.

Seventy nine animals (36\%) were resighted at least once during the 12 year study period, while the remaining 138 (64\%) were never seen again (Fig. 3). The minimum interval between the first and the last sighting of an individual animal was nine days. Twenty two animals (Tab. II) were resighted for the last time more than five years after the first sighting. One individual resighting maximum interval was $11.25 \mathrm{yr}$, two at $\sim 9 \mathrm{yr}$, two at $\sim 8 \mathrm{yr}$, three at $\sim 7 \mathrm{yr}$, nine at $\sim 6 \mathrm{yr}$ and five at $\sim 5 \mathrm{yr}$. The average length of time between the first and the last sighting was 40.6 ( \pm 31.1) months (Fig. 4).

\section{DISCUSSION}

Dolphins were found during all surveys and seasons (Tab. III, Fig. 2) and so we found no apparent seasonality in the way the animals use this habitat. The $145 \mathrm{~km}^{2}$ area used by the animals is more similar to oceanic waters than the inner reaches of the bay (saltier, cooler, less turbid - Simão \& Poletto 2002). This preference may be due environmental conditions or the associated difference in prey abundance (SIMÃo \& PoletTo 2002). S. guianensis was found in $42 \%\left(137 \mathrm{~km}^{2}\right)$ of Guanabara Bay (Rio de Janeiro) with an estimated 70 animals (AzEvedo et al. 2004, 2007). Comparing the two bays, while the area used is similar, Guanabara Bay has fewer individuals than Sepetiba, suggesting that resources are perhaps more limiting at the former. Also, Sepetiba Bay has the second largest concentration of estuarine dolphins in its range (SIMÃo et al. 2000), suggesting that resources are plentiful here.

Site fidelity has been studied in a variety of dolphin species, including Tursiops truncatus (e.g. BaLlance 1990, BRIstow \&

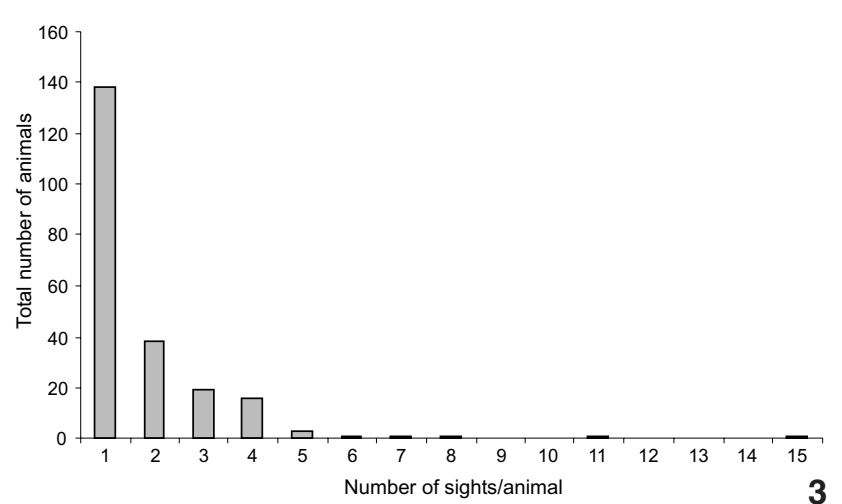

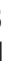
. 


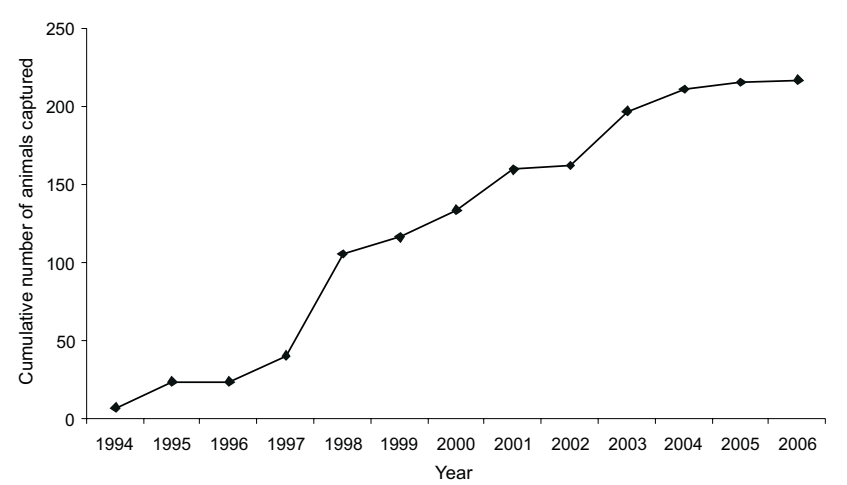

Figure 4. Cumulative curve of dolphins photo-identified at Sepetiba Bay.

Table III. Number of censuses by season for each year of study.

\begin{tabular}{lccccc}
\hline Years & Number of surveys & Spring & Summer & Autumn & Winter \\
\hline 1994 & 4 & 1 & 1 & 1 & 1 \\
1995 & 1 & 0 & 1 & 0 & 0 \\
1997 & 2 & 0 & 2 & 0 & 0 \\
1998 & 18 & 3 & 8 & 6 & 1 \\
1999 & 4 & 1 & 1 & 1 & 1 \\
2000 & 8 & 6 & 1 & 0 & 1 \\
2001 & 10 & 0 & 2 & 5 & 3 \\
2002 & 5 & 1 & 1 & 1 & 2 \\
2003 & 5 & 0 & 4 & 0 & 1 \\
2004 & 8 & 2 & 4 & 0 & 3 \\
2005 & 5 & 2 & 4 & 0 & 0 \\
2006 & 2 & 0 & 0 & 1 & 1 \\
\hline
\end{tabular}

of Bahia) for three years (Rossi-SANTos et al. 2007). With our results, Sepetiba Bay seems to offer a particularly high quality habitat, since dolphins are more abundant and found year round. Also, reproduction is common, since amny calves have been observed and photographic images of new individuals are obtained constantly (Fig. 4). Thus, the relatively few resightings (36\% of the animals identified) here compared with a greater resighting rate in the other study areas (North Bay 94\%, Cananéia Estuary - 85\%, Guanabara Bay - 94\%; FLores 1999, SANTos et al. 2001, Azevedo et al. 2004), may be a consequence of the number of field trips conducted which were insufficient to cover the entire sample population Residence patterns of cetaceans usually consider three parameters: the number of times an individual is resighted, the interval between the first and last sighting, and the average number of days between consecutive sightings of a single animal (BALLANCE 1990). These three parameters must be interpreted carefully to avoid misinterpretation. Combining the data shown in tables I and II and figure 3 suggests that the residence pattern of dolphins in Sepetiba Bay is variable, i.e., most of the individuals were seen just once whilst some were observed on many occasions. Also, some dolphins were resighted after a short interval of time (i.e., a few days later the first sighting), while others were resighted after a long interval, hence the average interval between resightings and the large standard deviation (40.6 231.1 months). A large variability in resighting interval is expected due to residence patterns that vary between individuals because of individual variation in the way they explore the environment for essential activities such foraging and reproduction (Ballance 1990, Karczmarski et al. 1999). Also, non-sightings do not necessarily imply absence, but may often be because the animal could not be photoidentified. This is especially important to our study because the Sepetiba Bay comprise the largest population of this species.

Group composition in dolphins is important for the evaluation of residence patterns. That mothers with calves are found all year round and in all 12 years of study suggest that this bay is an important nursing area and that most of the photo-identified animals are adult females. This and the infrequent exclusively adult groups (20\%) suggests that Sepetiba Bay is not always used by the entire local population. Females with calves and subadults of both sexes may use this bay until maturation of the offpspring. Once becoming adults, individuals may then move to join other adults in adjacent areas, such as the open ocean or other nearby bays (Fig. 5). As a preliminary test of this prediction, the photo-id catalogues of Sepetiba and Guanabara bays were compared and no common individuals were found, despite the relatively short distance between the two $(91 \mathrm{~km})$.

A large population of $S$. guianensis dolphins is commonly seen in Paraty Bay (Lodi \& Hetzel 1998, Fig. 5) and dolphins are often observed in ocean waters between Sepetiba and Paraty Bays (Sérgio C. Moreira, Instituto Aqualie, pers. comm.). Since both areas are environmentally similar, offering resources and shelter against predators, it is likely that the habitat of the $S$. guianensis population includes Sepetiba and the nearby $(<40 \mathrm{~km})$ Paraty Bays. To test this prediction, preparation of a photo-id catalogue of Paraty Bay estuarine dolphins is underway in our lab. We predict that both areas are used by individuals that were recorded in Sepetiba Bay. If so, the conservation concerns for these animals will have to take in account a much larger area. As anthropogenic influences rapidly increase in Sepetiba Bay, due to its economic interest for the state of Rio de Janeiro, Paraty Bay may become an important refuge should conditions worsen in Sepetiba.

The residence patterns described here provides preliminary data on the dynamics of the $S$. guianensis population of Sepetiba Bay. Data suggest that relatively few adults regularly use the bay, due to the long time intervals between resightings, and that those that use the bay are mainly reproducing females. Systematic long-term photo-identification of dolphins in 


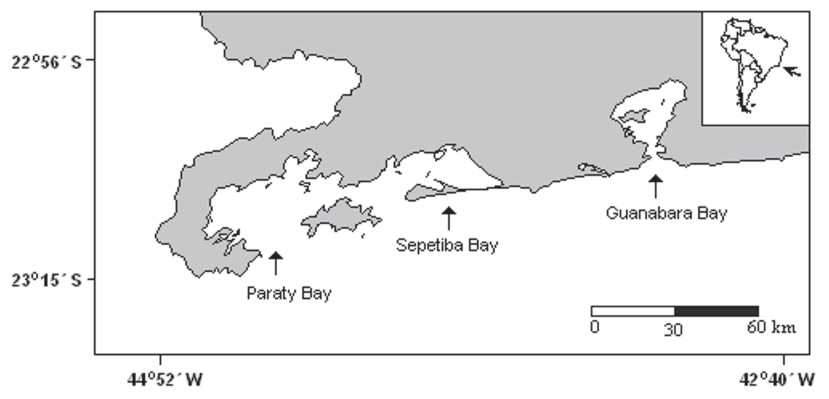

Figure 5. Map of the southern Rio de Janeiro coast with the geographic locations of the three bays described.

Sepetiba Bay with the inclusion of Paraty Bay, should provide a more comprehensive understanding, and result in more accurate conclusions regarding the habitat of $S$. guianensis. The knowledge of the relationship between these cetaceans and the environment will be extremely valuable for the implementation of future conservation programs.

\section{ACKNOWLEDGMENTS}

We wish to thank the Fundação O Boticário de Proteção à Natureza for financial support, as well as the trainee students and Ecovolunteers who took part in the project. Also, thanks to Romildo C. da Silva for his invaluable skill in driving the research boat and especially for his friendship over the years.

\section{LITERATURE CITED}

Azevedo, A.F. \& M. van Sluys. 2005. Whistles of the tucuxi dolphin (Sotalia fluviatilis) in Brazil: comparisons among populations. Journal of Acoustic Society of America 117 (3): 1456-1464.

Azevedo, A.F.; J. Lailson-Brito Jr; H.A. Cunha \& M. van Sluys. 2004. A note on site fidelity of marine tucuxis (Sotalia fluviatilis) in Guanabara Bay, southeastern Brazil. Journal of Cetacean Research and Management 6 (1):265-268.

Azevedo, A.F.; A.M. Oliveira; S.C. Viana \& M. van Sluys. 2007. Habitat use by marine tucuxi (Sotalia guianensis) (Cetacea, Delphinidae) in Guanabara Bay, south-eastern Brazil. Journal of the Marine Biological Association of the United Kingdon 87 (1): 201-205.

BALLANCE, L.T. 1990. Residence patterns, group organization, and surfacing associations of bottlenose dolphins in Kino Bay, Gulf of California, Mexico, p. 267-284. In: S. Leatherwood \& R.R. Reeves (Eds). The Bottlenose Dolphin. San Diego, Academic Press, 653p.

BigG, M.A.; P.F. Olesiuk; G.M. Ellis; J.K.B. Ford \& K.C. Balcomb. 1990. Social organization and genealogy of resident killer whales (Orcinus orca) on the coastal waters of British Columbia and Washington State, p. 383-405. In: P.S. Hammond; S.A. Mizroch \& G.P. Donovan (Eds). Individual recognition of cetaceans: use of photo-identification and other techniques to estimate population parameters. Cambridge, International Whaling Commission, special issue 12, 440p.

Borobia, M.; S. Siciliano; L. Lodi \& W. Hoek. 1991. Distribution of the South American dolphin Sotalia fluviatilis. Canadian Journal of Zoology 69 (4): 1025-1039.

Bräger, S.; S.M. Dawson; E. Slooten; S. Smith; G.S. Stone \& A. Yoshinaga. 2002. Site fidelity and along-shore range in Hector's dolphin, an endangered marine dolphin from New Zealand. Biological Conservation 108 (3): 281-287.

BRISTOW, T. \& E.I.S. ReEs. 2001. Site fidelity and behaviour of bottlenose dolphins (Tursiops truncatus) in Cardigan Bay, Wales. Aquatic Mammals 27 (1): 1-10.

CARR, T. \& R.K. BONDE. 2000. Tucuxi (Sotalia fluviatilis) occurs in Nicaragua, $800 \mathrm{~km}$ North of its previously known range. Marine Mammal Science 16 (2): 447-452.

Defran, R.H.; G.M. Schultz \& D.W. Weller. 1990. A technique for the photographic identification and cataloging of dorsal fins of the bottlenose dolphin (Tursiops truncatus), p. 53-55. In: P.S. HAMmond; S.A. Mizroch \& G.P. Donovan (Eds). Individual recognition of cetaceans: use of photo-identification and other techniques to estimate population parameters. Cambridge, International Whaling Comission, special issue 12, 440p.

FLORES, P.A.C. 1999. Preliminary results of a photo-identification study of the marine tucuxi Sotalia fluviatilis in southern Brazil. Marine Mammal Science 15 (3): 840-847.

Gonzalez, F.T. 1994. The use of photo-identification to study the Amazon river dolphin Inia geoffrensis, in the Colombian Amazon. Marine Mammal Science 10 (3): 348-353.

Gunnlaugsson, T. \& J. Sigurjónsson. 1990. A note on the problem of false positives in the use of natural marking data and abundance estimation, p. 143-145. In: P.S. HAMmond; S.A. Mizroch \& G.P. Donovan (Eds). Individual Recognition of Cetaceans: use of photo-identification and other techniques to estimate population parameters. Cambridge, International Whaling Commission, special issue 12, 440p.

Hammond, P.S.; S.A. Mizroch \& G.P. Donovan. 1990. Individual recognition of cetaceans: use of photo-identification and other techniques to estimate population parameters. Cambridge, International Whaling Commission, special issue 12,440 p.

IUCN. 2006. 2006 IUCN Red List of Threatened Species. Available on line at: http://www.iucnredlist.org [Accessed in 12.VII.2007]

Karczmarski, L.; P.E.D. Winter; V.G. Cockcroft \& A. McLachlan. 1999. Population analyses of Indo-Pacific humpback dolphins Sousa chinensis in Algoa Bay, Eastern Cape, South Africa. Marine Mammal Science 15 (4): 1115-1123.

Lodi, L. \& B. Hetzel. 1998. Grandes agregações do boto-cinza (Sotalia fluviatilis) na Baía da Ilha Grande, Rio de Janeiro. Bioikos 12 (2): 26-30.

Marques, A.N.; R.B.C. Moraes \& M.C. Maurat. 2002. Poluição 
Marinha, p. 311-334. In: R.C. Pereira \& A. Soares-Gomes (Eds). Biologia Marinha. Rio de Janeiro, Editora Interciência, 382p.

Marten, K. \& S. Psarakos. 1999. Long-term site fidelity and possible long-term associations of wild spinner dolphins (Stenella longirostris) seen off Oahu, Hawaii. Marine Mammal Science 15 (4):1329-1336.

Mayr, E. 1977. Populações, espécies e evolução. São Paulo, Universidade de São Paulo, 485p.

Muehe, D. \& E. Valentins. 1998. O litoral do Rio de Janeiro: uma caracterização físico-ambiental. Rio de Janeiro, FEMAR, 123p.

Rossi-Santos, M.R. \& J. Podos. 2006. Latitudinal variation in whistle structure of the estuarine dolphin Sotalia guianensis. Behaviour 143 (3): 347-364.

Rossi-Santos, M.R.; L.L. Wedekin \& E.L.A. Monteiro-Filho. 2007. Residence and site fidelity of Sotalia guianensis in the Caravelas River Estuary, eastern Brazil. Journal of Marine Biological Association of United Kingdon 87 (1): 207-212.

SANTOS, M.C.O.; L.B. AcUÑa \& S. Rosso. 2001. Insights on site fidelity and calving intervals of the marine tucuxi dolphin (Sotalia fluviatilis) in south-eastern, Brazil. Journal of the Marine Biological Association of the United Kingdom 81 (6): 1049-1052.

Scott, M.D.; R.S. Wells; A.B. Irvine \& B.R. Mate. 1990. Tagging and marking studies on small cetacean, p. 489-514. In: S. Leatherwood \& R.R. Reeves (Eds). The Bottlenose Dolphin. San Diego, Academic Press, XVIII+653p.

Simão, S.M. \& F.R. PoletTo. 2002. Áreas preferenciais de pesca e dieta do ecótipo marinho do boto-cinza (Sotalia fluviatilis) na Baía de Sepetiba. Floresta e Ambiente 9 (1): 18-25.

Simão, S.M.; J.L.A. Pizzorno; V.N. Perry \& S. Siciliano. 2000. Aplicação da técnica de foto-identificação do boto-cinza, Sotalia fluviatilis (Cetacea, Delphinidae) da Baía de Sepetiba. Floresta e Ambiente 7 (1): 31-39.

Simões-Lopes, P.C. 1988. Ocorrência de uma população de Sotalia fluviatilis (Gervais, 1853) (Cetacea, Delphinidae) no limite sul de sua distribuição, Santa Catarina, Brasil. Biotemas 1
(1): 57-62.

Simões-Lopes, P.C. \& M.E. Fabian. 1999. Residence patterns and site fidelity in bottlenose dolphins, Tursiops truncatus (Montagu) (Cetacea, Delphinidae) off Southern Brazil. Revista Brasileira de Zoologia 16 (4): 1017-1024.

Sloteen, E.; S.M. Dawson \& H. Whitehead. 1993. Associations among photographically identified Hector's dolphins. Canadian Journal of Zoology 71 (12): 2308-2311.

Stevick, P.T.; P.J. Palsboll; T.D. Smith; M.V. Bravington \& P.S. Hammond. 2001. Errors in identification using natural markings: rates, sources, and effects on capture-recapture estimates of abundance. Canadian Journal of Fisheries and Aquaculture Science 58 (9): 1861-1870.

Weigle, B. 1990. Abundance, distribution and movements of bottlenose dolphin (Tursiops truncatus) in lower Tampa Bay, Florida, p. 195-201. In: P. S. Hammond; S.A. Mizroch \& G.P. DONOVAN (Eds). Individual recognition of cetaceans: use of photo-identification and other techniques to estimate population parameters. Cambridge, International Whaling Commission, special issue 12, 440p.

WeLLS, R.S. 1991. The role of long-term study in understanding the social structure of a bottlenose dolphin community, p. 199-223. In: K. PrYor \& K.S. NorRIS (Eds). Dolphin societies: discoveries and puzzles. Berkeley, University of California Press, 397p.

White, G.C. \& R.A. Garrot. 1990. Analysis of wildlife radiotracking data. New York, Academic Press, 383p.

WÜRSIG, B. \& M. WÜRSIG. 1977. The photographic determination of group size, composition, and stability of coastal porpoises (Tursiops truncatus). Science 198 (4318): 755-756.

WÜrsig, B. \& T.A. JefFerson. 1990. Methodology of photoidentification for small cetaceans, p. 43-52. In: P.S. HAMMOND; S.A. Mizroch \& G.P. Donovan (Eds). Individual recognition of cetaceans: use of photo-identification and other techniques to estimate population parameters. Cambridge, International Whaling Commission, special issue 12, 440p.

Submitted: 23.IV.2007; Accepted: 30.V.2008.

Editorial responsibility: Lena Geise 